\title{
EDITORIAL
}

\section{In This Issue: Subtle Clinical Policy}

Kurt C. Stange, $M D, P b D$, Editor

Conflicts of interest: none reported

Ann Fam Med 2005;3:386-388. DOI: 10.1370/afm.394.

\section{TESTING FOR ACUTE HIV INFECTION DEMANDS A SUBTLE CLINICAL POLICY}

I

$\mathrm{n}$ this issue, 2 related analyses make the case that it

is cost-effective to test for acute HIV disease among

outpatients with acute viral illness symptoms. ${ }^{1,2}$

An editorialist argues that cost-effectiveness analyses

should not be used to guide the care of individual

patients-that "cost-effectiveness analysis is designed

for policy rather than clinical use." 3 These articles pro-

vide a chance to consider how we use data and integrative research, such as cost-effectiveness analyses, to make policy and individual decisions.

I believe that the value of cost-effectiveness analyses, such as the one in this issue, extends beyond the yes or no answers they generate. If we look past the bottom line for the general population, these analyses can inform our judgment in personalizing decisions for individuals based on what Ian McWhinney called "an acquaintance with particulars." ${ }^{14}$ For the decision to test for acute HIV infection among patients with viral symptoms, Coco's cost-effectiveness analysis ${ }^{1}$ provides data on the important general factors to consider: the patient's specific viral symptoms, the prevalence of HIV infection in outpatients with such symptoms, ${ }^{2}$ and the characteristics of the available tests. In the vernacular of clinical guidelines and evidence-based medicine, many will judge there to be insufficient evidence to make a general recommendation to test all primary care outpatients, with even selected viral symptoms, for acute HIV infection. Authors of a recent analysis focused on screening the general population for HIV came to a similar conclusion. ${ }^{5}$

The appropriately conservative evidence-based medicine (EBM) criteria for making general recommendations mask the great subtlety of excellent clinical care. ${ }^{6}$ The judgment that data are insufficient to make a general policy recommendation is not the same as judging that the evidence is insufficient in specific patient populations or individuals. Too heavy-handed an application of EBM can result in the de-intellectualization and depersonalization of practice.
We need to guard against the insidious effect of a laudable focus on scientific evidence in devaluing the importance of focusing on the particulars of patients, families, communities, and local practices. This insidious effect is apparent in continuing education forums in which subtle insights not based on population studies are spoken of apologetically or sometimes not at all. The effect is seen in some clinicians trained during the EBM era, who do not feel empowered to use their intuition to go beyond classic scientific evidence to engage different ways of knowing. It is seen in a model of practice that forces the 10-minute visit for financial survival rather than allowing the time for relationships and on-the-ground knowledge to guide subtle practice. Paying for performance, when the performance is based on the tyranny of what can be measured rather than on paying attention to the particulars, has the potential to squelch the subtlety and personalization of our practice. More hopeful options are found in system transformation efforts that aim to support sophisticated individualization of care. ${ }^{7-11}$ Further guidance is found in the call by one of the founders of EBM for the unification of both evidence-based policy guidelines and evidence-based individual decision making ${ }^{12}$ and in a clinical and research framework that integrates different ways of knowing. ${ }^{13}$

In my practice, the cost-effectiveness analysis by Coco in this issue has led to a subtle change. I am not ready to recommend testing for acute HIV infection to even a minority of patients in my practice with viral symptoms - there is no formal policy change as a result of this study. This analysis, however, has made me look for information on the prevalence of HIV disease in my practice population and in my community. It has made me consider the possibility that certain viral symptoms may be a harbinger of acute HIV infection. I now ask more about HIV risk factors in patients and partners and will, on occasion, discuss testing for HIV infection among some patients with viral illness. I also consider both the potentially beneficial and harmful effects of even asking about the risk of HIV infection, although 
the available evidence doesn't apply well to the situation of patients with acute viral symptoms.

Cost-effectiveness analysis can lead to general clinical rules-policy at 10,000 feet. Clinical care is provided by community-based practices at the level of individuals and families - policy on the ground. A combination of support for general strategies at 10,000 feet and freedom to implement subtle clinical policies on the ground is needed to provide care that is both effective and cost-effective.

\section{STUDIES OF CLINICAL PHENOMENA AND PRACTICE APPROACHES}

A careful qualitative study by Walter and colleagues ${ }^{14}$ in this issue identifies how patients understand the meaning of their family history of cancer, heart disease, and diabetes. The findings are important for efforts to inform patient- and family-centered risk assessment and communication.

Epstein and colleagues ${ }^{15}$ used a covert standardized patient to evaluate physicians' patient-centered communication. They find that greater patient-centeredness is associated with lower rates of diagnostic testing and greater health care expenditures, but also with increased visit length. Without reimbursement systems that recognize this trade-off, the systems and patient benefits of a patient-centered approach are paid for by the primary care clinician and are thus disincentivized.

An interesting study of pneumonia treatment in nursing home patients takes advantage of the natural experiment of intercountry practice differences. ${ }^{16}$ The authors find that patients' health status appears to be more important than the aggressiveness of antibiotic treatment in mortality among nursing home residents with lower respiratory tract infection.

In an intensive mixed methods study of Midwestern family medicine practices, Crabtree and colleagues ${ }^{17}$ examine the place of clinical preventive services among competing demands for provision of acute and chronic illness care. They find diverse practice approaches that focus on the clinical encounter, and they identify factors that may be useful in designing practice-individualized improvement strategies.

\section{METHODOLOGY STUDIES, SYSTEMATIC REVIEWS AND REFLECTIONS}

Two methodology studies show the value of a new measurement tool and of a novel application of a promising analysis technique. Shields and colleagues ${ }^{18}$ describe the development and validation of the theorybased Rochester Participatory Decision Making Scale. In another study, social network analysis ${ }^{19}$ is applied to characterize 2 family medicine practices. Previously used in public and community health settings, the authors find this technique to be valuable in quantitatively analyzing interaction patterns and in understanding differences between practices.

One systematic review finds evidence for common clinical practices that have been understudied in the primary care setting, whereas another review finds that the available data do not support an emerging clinical practice. Arroll and colleagues ${ }^{20}$ find that both tricyclic antidepressants and selective serotonin reuptake inhibitors are effective for treatment in primary care. This information is important because previous systematic analyses have not focused on the primary care setting. These authors find that the relatively low doses of tricyclic antidepressants sometimes used in primary care may be effective. The systematic review by Levri and colleagues ${ }^{21}$ finds insufficient evidence to support using metformin as treatment of overweight or obese adults without diabetes, or for treatment of nondiabetic women with polycystic ovary syndrome.

In an essay portraying a challenging patient, Neher ${ }^{22}$ shows how uncovering a remote traumatic event helps to understand past missed opportunities while requiring great care to manage the resulting anger and its potential consequences. Interestingly, the online discussion ${ }^{23}$ of 2 articles from the last issue of Annals ${ }^{24,25}$ raises related issues about the importance and potential difficulties of uncovering past emotional traumas.

The impact of the research and essays in this issue will be enhanced by your interpretation. We invite all Annals readers to participate in the online discussion at http://www.AnnFamMed.org.

To read or post commentaries in response to this article, see it online at http://www.annfammed.org/cgi/content/full/3/5/386.

\section{References}

1. Coco AS. Cost-effectiveness of expanded testing for primary HIV infection. Ann Fam Med. 2005;3:391-399.

2. Coco AS, Kleinhans E. The prevalence of primary HIV infection in symptomatic ambulatory patients. Ann Fam Med. 2005;3:400-404.

3. Ganiats T. Should we screen patients with viral symptoms for HIV disease? Ann Fam Med. 2005;3:389-390.

4. McWhinney IR. An acquaintance with particulars... Fam Med. 1989;21:296-298.

5. Paltiel AD, Weinstein $M C$, Kimmel $A D$, et al. Expanding screening for HIV in the United States - an analysis of cost-effectiveness. $N$ Engl J Med. 2005;352:586-595.

6. Davis NL. The art of EBM [eletter]. http://www.annfammed.org/cgi/ eletters/3/3/271\#3337, 21 July 2005.

7. Sidorov J. We have a way to go! [eletter]. http://www.annfammed. org/cgi/eletters/3/4/300\#3477, 20 August 2005.

8. Singer GR. Chronic care model [eletter]. http://www.annfammed. org/cgi/eletters/3/4/300\#3456, 13 August 2005. 
9. Grant RW. Comment on "Impact of an electronic medical record on diabetes quality of care" [eletter]. http://www.annfammed.org/cgi/ eletters/3/4/300\#3436, 4 August 2005

10. Phillips LS. Comment on "Impact of an electronic medical record on diabetes quality of care" [eletter]. http://www.annfammed.org/cgi/ eletters/3/4/300\#3354, 27 July 2005

11. Betz Brown J. Beyond EMR reminders and alerts [eletter]. http://www. annfammed.org/cgi/eletters/3/4/300\#3362, 28 July 2005.

12. Eddy DM. Evidence-based medicine: a unified approach. Health Aff (Millwood). 2005;24:9-17.

13. Stange KC, Miller WL, MCWhinney I. Developing the knowledge base of family practice. Fam Med. 2001;33:286-297

14. Walter FM, Emery J. 'Coming down the line'- patients' understanding of their family history of common chronic disease. Ann Fam Med. 2005;3:405-414.

15. Epstein RM, Franks P, Shields C, et al. Patient centered communication and diagnostic testing. Ann Fam Med. 2005;3:415-421.

16. Kruse RL, Mehr DR, van der Steen JT, et al. Antibiotic treatment and survival of nursing home patients with lower respiratory infection: a cross-national analysis. Ann Fam Med. 2005;3:422-429.

17. Crabtree BF, Miller WL, Tallia AF, et al. Delivery of clinical preventive services in family medicine offices. Ann Fam Med. 2005;3:430-435.
18. Shields CG, Franks P, Fiscella K, Meldrum SC, Epstein RM. Rochester participatory decision making scale (RPAD): reliability and validity. Ann Fam Med. 2005;3:436-442.

19. Scott JG, Tallia AF, Crosson JC, et al. Social network analysis as an analytic tool for interaction patterns in primary care practices. Ann Fam Med. 2005;3:443-448.

20. Arroll B, Macgillivray S, Ogston S, et al. Efficacy and tolerability of tricyclic antidepressants and SSRIs compared with placebo in primary care treated depression. A meta-analysis. Ann Fam Med. 2005;3:449456.

21. Levri K, Slaymaker E, Last A, Yeh J, Ference J, D'Amico F, Wilson S. Metformin as treatment for overweight and obese adults: a systematic review. Ann Fam Med. 2005;3:457-461.

22. Neher JO. The decade dance. Ann Fam Med. 2005;3:462-463.

23. Annals of Family Medicine comments published in the past 30 days. On TRACK. Web site. Available at: http://www.annfammed.org/cgi/ eletters?lookup $=$ by_date\&days $=30$.

24. Malterud $\mathrm{K}$, Hollnagel $\mathrm{H}$. The doctor who cried: a qualitative study about the doctor's vulnerability. Ann Fam Med. 2005;3:348-352.

25. Shields SG. On this day of mothers and sons. Ann Fam Med. 2005:3:367-368

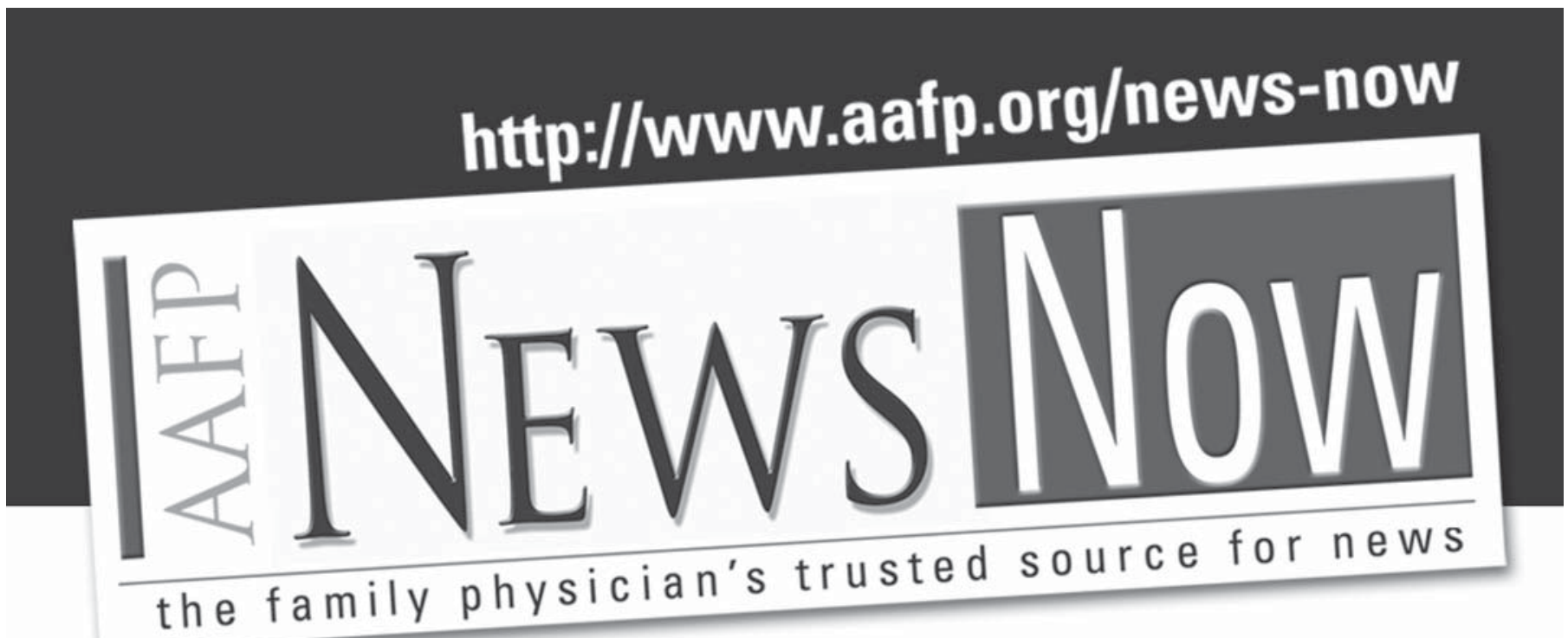

\section{Rely on AAFP News Now to learn what the Academy has done for you lately}

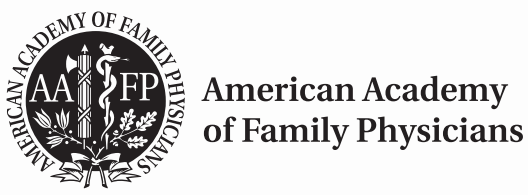

- News posted daily at http://www.aafp.org/news-now

-Weekly e-mail with links to top stories

- Monthly print version 